\title{
Assessing the Potential Contribution of Coffee-Based Tourism to the Rwandan Coffee Sector Development. The Case of Nyamasheke District
}

\author{
Modeste Uwimana, Denys Uwimpuhwe \\ University of Lay Adventists of Kigali (UNLAK), Kigali, Rwanda \\ Email: Umodes02@gmail.com
}

How to cite this paper: Uwimana, M., \& Uwimpuhwe, D. (2022). Assessing the Potential Contribution of Coffee-Based Tourism to the Rwandan Coffee Sector Development. The Case of Nyamasheke District. Open Journal of Business and Management, 10, 729-743.

https://doi.org/10.4236/ojbm.2022.102041

Received: December 3, 2021

Accepted: March 6, 2022

Published: March 9, 2022

Copyright $\odot 2022$ by author(s) and Scientific Research Publishing Inc. This work is licensed under the Creative Commons Attribution International License (CC BY 4.0).

http://creativecommons.org/licenses/by/4.0/

\begin{abstract}
Coffee farming sector is affected by two main factors; the coffee price at international market goes up and down depending on the current situation. On the other hands the cost of farms' inputs changes up-down due to inflation and others related factors. These factors have a negative impact on profitability of coffee farming to the extent that some farmers are demotivated. There is therefore a need for an innovative solution to this problem. The coffee-based tourism is regarded as a growth niche tourism market and may come up with solutions to problems the coffee sector is facing. This paper's main objectives are to assess the potential contribution of Coffee based tourism to the coffee sector, and to identify factors that may promote or hinder the coffee-based tourism development in Nyamasheke District. The study followed a qualitative research methodology. Data were collected through face-to-face interviews with ten Coffee Washing Stations managers, four farmers representing coffee farmers organizations and the District's Vice Mayor of economic affairs. Respondents were selected purposively because are not only involved in the coffee farming business but are also interested in the development of the coffee sector. The study found that Coffee Based Tourism may contribute to the improvement of coffee production as it may motivate coffee farmers to improve their farming activities, improve the coffee farmers' livelihood, and improve the coffee sector in Rwanda. The SWOT analysis presents factors that may promote or hinder the coffee-based tourism in that district. Strength and opportunities are the promoting factors, while weakness and treats depict the hindering factors. In addition, this paper con-
\end{abstract}


cludes by arguing that the success of this new venture would depend heavily on the central government and the local government's will through policy development and other supports needed to develop this business venture.

\section{Keywords}

Tourism, Cherry Coffee, Coffee Based Tourism, Farming, SWOT Analysis

\section{Introduction}

The agricultural context has gone through several structural changes in the last decades, including the development of different enterprises using farm resources (Nickerson et al., 2001). Diversifying a farm to include recreation and leisure activities into agritourism is increasingly being adopted in the United States and is suggested to bring a myriad of economic and intrinsic benefits to farmers, visitors and communities. Agritourism promises the benefits of keeping family farms in business and preserving American agricultural heritage, maximizing the productivity of farmland resources through their recreational use, and even improving the economic situation of local communities (Veeck et al., 2006).

Agro-tourism is defined as a combination of natural settings and products of agricultural operations combined within a tourism experience. It is developing into a large part of the tourism industry. It is one of important types of tourism in Germany Austria, Greece, Poland, China Jamaica, and other part of Europe and America (Sharpley \& Vass, 2006). The global consumption patterns, taste and attitude towards food, leisure tourism activities and human interest towards nature and traditional culture and heritage have opened new opportunities for the rural producers in the form of agritourism (Thapa, 2013). The agritourism provides additional income source and employment opportunity to the traditional farmers and rural peoples (Thapa, 2013). Agritourism is best seen as a stabilizing economic force, providing a supplemental income that is optimally paired with active farms (Thorp, 2015). Agritourism's beneficiaries are most likely to be farm owners (especially farm women), with little measurable increase in local retail business (Thorp, 2015). Agritourism is a direct marketing activity which provides additional opportunities to farmers to reduce risks involved in farming via diversification in a competing and urbanizing economic environment (Govea \& Lin, 2015).

In the East Africa Community, there Tanzania can be the example, where tourism contributes directly and indirectly at 14\% of Tanzania's GDP in 2014 with USD 6.7 billion. Agri-tourism in Tanzania is known also as a Pro-Poor Tourism (PPT), and it offers market opportunities to the small scale farmers as well as large producers. In the united republic of Tanzania, the younger graduate 
and other agricultural entrepreneurs have testified that agro-tourism for them is a key element to the food quality consistency, and also it plays a critical role to the production traceability and encourages them the record keeping, those are helpful for attracting the tourists and sometime the buyers (ACT, 2018). Agritourism in Tanzania enables the farmers to meet a good agriculture practices (GAP) and a good handling practices (GHP). GAP and GHP are the better tools for competing to the international market and for fulfilling the production standard's requirement (ACT, 2018).

Rwanda Government has identified Tourism Sector as a priority sector to facilitate the achievement of the country's development goals. Rwanda's current Sustainable Tourism Master Plan (STMP) recommends the formation of business linkages across the supply chains, especially for agricultural produce and handicrafts from the rural sector, in order to spread the benefits of tourism more widely. Agriculture is the mainstay of the economy particularly in the rural areas where incomes and employment are mainly dependent on the sector (UN-Rwanda, 2014). The aim of this study was to assess the potential contribution of the Coffee Based Tourism on the Rwandan coffee sector. It is composed of two-three main parts; the first part puts in the perspective the problem studied. The second part shat the possible contribution of coffee based tourism on the coffee sector, the last section discusses different factors that may affect the success of this new tourism product.

\section{The Rational of This Study}

Coffee plays a major role in the Rwandan economy. It contributes significantly to foreign exchange earnings and to the monetization of the rural economy. However, the Rwandan coffee is less than $1 \%$ of the world market and it has no influence on futures prices. Rwanda coffee price is depending on New York coffee market, and the increase or decrease of the New York coffee market directly affect to the Rwanda coffee price (CBI, 2018). Taking only into account quality and volume, Rwanda has little competitive advantage compared to the other specialty coffee producing countries in East Arica, where its competitive advantage is very much related to its "storytelling" capacity, its pricing, its Coffee Washing Station infrastructure, and the ease of traveling and doing business (CBI, 2018).

Many researchers have demonstrated how the Rwandan tourism products should be diversified (Ashley, 2007; Anbalagan \& Lovelock, 2014) and recommended that coffee should be regarded as tourism product add-on. However, only one research on coffee based tourism was conducted by Anbalagan \& Lovelock (2014).

This study identified the possible contribution of coffee based tourism to the Rwanda Development. The study was published in 2014, eight years ago, yet the recommended coffee based tourism is not yet developed and marketed along other new tourism products the Rwandan government is selling. The aim of 
this study is to extend the study of Anbalagan \& Lovelock (2014) by analyzing the potential contributions of coffee based tourism to the coffee sector in Rwan$\mathrm{da}$, focusing on Nyamasheke district. This district is number one in producing more coffee in Rwanda according to (NAEB, 2016). This study was guided by the following objectives; to assess the potential contribution of Coffee based tourism to the coffee sector in Nyamasheke district; and to identify factors that may promote or hinder the coffee based tourism development in the case studied.

\section{Coffee Sector in Rwanda}

According to the last coffee census of 2015, in Rwanda there are 355,771 coffee growers, with $89,726,809$ of total coffee trees that covered the area of 35,891 ha. In Rwanda also, there are 245 coffee washing station with the processing capacity of 104,600 tons of coffee cherries per season (NAEB, 2016). The National Strategic for Transformation (NST1) has shown that the percentage of fully washed coffee is targeted at $80 \%$ of total production by 2024 , while the productivity per tree should by that time have increased to $4 \mathrm{~kg}$ (MINAGRI, 2018). Coffee production in Rwanda was introduced in 1904 by German missionaries. Since the early 1950s, it has gradually undergone substantial development resulting from proper farm management. Owing to Rwandan soil characteristics, which are suitable for coffee production, coffee plantations are found in all four provinces of the country. Arabica and Robusta are the major coffee species cultivated in Rwanda. Arabica coffee occupies approximately 95\% of the country's total coffee plantations and is mostly planted at higher altitudes in the Southern, Northern, and Western Provinces of Rwanda. Robusta coffee comprises the remaining 5\% and is planted at lower altitudes below $1400 \mathrm{~m}$ in the Eastern Province (MINAGRI, 2018). Despite its significant contribution in the Rwandan economy, the coffee production sector is facing a number of challenges, mainly low productivity. Coffee yields in most of the East African counties lag behind Latin-America and Asia.

In Rwanda, the average annual coffee yields varied between 1.5 and 2 tons per ha from 2012 to 2016. In contrast, in the same period, the average annual coffee yields were around 8 tons per ha in Colombia, Venezuela, and Indonesia. Coffee production was devastated during the genocide and civil war, and then gradually revived, but was stopped in 2004/2005. The current level of productivity was never recovered fully after 1994 genocide against Tutsi in Rwanda. The low level of coffee yield is the result of various environmental, institutional, and farm management challenges. Pests and diseases such as coffee berry disease and coffee leaf rust are the primary limitations for crop productivity. Moreover, the inability of farmers to adopt good agronomic practices such as weeding, mulching, pruning, use of improved varieties, fertilizers, and soil erosion control can also threaten coffee yields (MINAGRI, 2018). 


\section{COFFEE MAP IN NYAMASHEKE DISTRICT}



Coffee map of Nyamasheke district. Source: GIS NAEB, 2020. 
Nyamasheke district is the one of the districts of Western Province of Rwanda. Nyamasheke district is divided into 15 sectors (imirenge): Ruharambuga, Bushekeri, Bushenge, Cyato, Gihombo, Kagano, Kanjongo, Karambi, Karengera, Kirimbi, Macuba, Nyabitekeri, Mahembe, Rangiro, Shangi, it is also divided into 68 cell (utugari), and 588 village (imidugudu), Nyamasheke district also has 1174 square kilometers (NISR, 2012). Nyamasheke district is the most coffee growing in Rwanda with 43,518 coffee farmers, with 13,032,732 of total coffee trees, and more than 39 coffee washing station were installed and operated in that district (NAEB, 2016). Coffee production has been at the core of farm family livelihoods for many generations, and today it serves as source of cash income for over 355,000 coffee farmers in Rwanda even if the income from the coffee production is still insufficient to the farmers relating to the farms input (Clay et al., 2016).

\section{Coffee Based Tourism}

Coffee based tourism is related to the consumption of the coffee, history, traditions, products and culture of a destination. Although literature in the field of coffee tourism is limited, researchers have inter-linked notions of coffee and tourism in a number of different ways that separately or collectively provide potential tourism products. The growth of coffee production and consumption, and an increasing number of coffee-related establishments worldwide suggest that there is a case for coffee-based tourism to be regarded as a growth niche tourism market (Anbalagan \& Lovelock, 2014). Coffee based tourism is subset of rural tourism which believed to have been started in late nineteenth century in Hawaii where coffee was included as part of luxurious vegetation of the uplands, where some tourists had travel experience related to coffee in the region (Woyesa \& Kumar, 2021). The whole issue is that rural tourism based on coffee would improve community income and may alter the expansion of agriculture to sensitive forests. The concept of rural tourism has been popularized in decades mainly to counter the restructuring of western economy that demanded diversification of rural economy and rejuvenation of rurality (Woyesa \& Kumar, 2021). The term "rural tourism" sometimes used interchangeably with "agri-tourism", "farm tourism", and "farm-based tourism" and sometimes used in a different, even though some sources claim rural tourism is a comprehensive development approach combining ecotourism, farm tourism, and agri-tourism in a rural setting (Woyesa \& Kumar, 2021).

\section{Research Methodology}

Research methodology is a way to systematically solve the research problem. This study followed the qualitative methods, which adopts a holistic view that seeks discovery from involvement in the actual experience and aims to provide an in-depth understanding of social phenomena by exploring and interpreting collected data (Williams, 2011).

This method helped participants to express their feelings beyond the struc- 
tured questionnaires, hence giving a detailed description and clarify on their perception toward the potential contribution of Coffee-Based Tourism (C.B.T) to the study area (Nyamasheke district).

\section{Respondents}

Participants of this study were selected using purposive sampling technique. Respondents were selected according to their participation in coffee industry as well as their capacity to provide reliable data. Data were collected from July to August 2020 on the following respondents: ten coffee washing stations (cws)'s managers and some coffee farmers' representative. The interviewed managers and coffee farmers were from the following coffee washing station: Nyagatare cws, COOPAC Nyabumera cws, Gitwe cws, Karambi cws, Gasharu cws, Kirambo cws, Rugali cws, Muhororo cws, Shara cws, and Kivu Belt Coffee cws. To substantiate the date from the interviews, a document review was conducted.

This study reviewed the following documents: the District Development Plan 2013, the Rwandan tourism policy 2009, and the National Agriculture Export Development Board 2016.

Data were analyzed using content analysis. This technique was employed to analyze data collected during the face-to-face interviews and documents review. Furthermore, a SWOT analysis was used to find out factors that may promote of hinder the CBT in the Nyamasheke District.

\section{Findings}

Coffee based tourism is a branch of agri-tourism which is based on coffee sector, and covers all value chain. According to Mahaliyanaarachchi (2014).

Agri-tourism can be categorized into four types, namely: Farm Stay, Farm Catering, Farm Tours and Farm Retailing. As farmers are trying to diversify their economies due to low profits and high risks, agri-tourism offers a complementary/supplementary income source that allows a large financial leverage for capital expenditure, depending on how much the entrepreneur wants to invest (Mahaliyanaarachchi, 2014).

\subsection{The State of Coffee Productivity in Nyamasheke District}

If you try to compare the cost of coffee production and benefits the farmers get in this district, famers are not getting their return on investment made in their activities. Both farmers who participated to this study indicated that coffee farming is really not profitable. When they were asked about the cause of the loss in coffee business, respondents were divided in their views regarding the perceived causes. Two respondents revealed that the cost of production make the coffee business less profitable. "In fact, when I look at the work a coffee farmer does in coffee production, and look at what he gets in return, in reality the money a farmer earns is not repaying the farmer's investment within production period" (Coffee farmer 1). 
Two respondents disagreed with the previous respondents regarding the cause of the loss incurred by farmers. In their views, the profitability in coffee business depends on the efforts the farmer put in his/her activities. If the famer is motivated and invest enough time and money in his/her farm, the yield would be good. "The income is not good enough, but it depends on how well the coffee is taken care of. The well cared for coffee, produces a satisfactory yield" (Coffee farmer 2).

Another factor which makes coffee business unprofitable is unstable price of coffee cherries. According to our respondents, the price goes higher or low and farmers has no influence over it. Sometimes the price is one hundred and ten, and sometimes the price is two hundred or more. When it rises to about three hundred and fifty, where the farmer can take care of the coffee and make a profit. "You see there is a time when at least they give us about three hundred francs per kilo, plus ten to be able to deliver it to the factory. That time the farmer was able to earn a living wage, and then he was able to make a living" (Coffee farmer 3).

Coffee farmer 1 also supported the above idea suggesting that $300 \mathrm{Rwf} / 1 \mathrm{~kg}$ of cherries coffee would be good for a farmer but not best.

"If at least a farmer was getting than three hundred per kilo would help us because that is where one can get the benefit of coffee. In fact, the price we get for coffee is not good" (Coffee farmer 1).

This study supports the views of past researchers who identified the challenges of coffee farmers. Woyesa and Kumar (2021) revealed in Ethiopia forest and semi-forest coffee production system which is relatively compatible with sustainability is losing its significance due to low yield and net profit. As a result, farmers are diverting to agriculture, which is threatening the survival of the moist montane ecosystem and the gene pool of wild Arabica coffee. COVID-19 has worsened the farmers' situation. According to the International Coffee Organization (2020), due to COVID-19, the livelihoods of coffee farmers are increasingly under pressure as farm revenues decrease while costs for inputs and expenditures for food and non-food items are on the rise.

\subsection{Awareness of Coffee-Based Tourism}

Respondents were asked to indicate another business that could be introduced in the area to support people involved in the coffee business. The aim was to know if CWS managers are aware of the coffee tourism as a new product. Surprisingly, among all suggestions given by our respondents, none of them was related to tourism. However, past researchers have revealed the role of agri-tourism entrepreneurship development in agriculture sector. Khanal \& Shrestha (2019) asserted that agri-tourism is one of the most crucial parameters to improve the nation's economy of a country like Nepal, where major occupation was farming and having lots of potential tourist destination hubs. Rural areas where agri-tourism is exercised became the places where all elements of local sustainable develop- 
ment collected. Agri-tourism authorized new businesses and jobs on the local level. It also acted on the policymaking system of the locality; forcing it indirectly to find sources of financing for achieving objectives. It also expanded the farmer's income (Khanal \& Shrestha, 2019).

\subsection{Potential Benefits from Coffee Tourism}

Coffee Washing Station managers were asked to indicate the possible benefits of a coffee-based tourism, where someone would come and be introduced to coffee farming, be explained the process from coffee planting to coffee harvest, then be shown how coffee is processed and he pay for it, as it is done in other countries. All agreed that the CBT has the potential to contribute positively to their business and indicated their expectation. Some of benefits identified are the following: "motivating coffee farmers to improve their activities, to improve the coffee farmers' livelihood, and boosting coffee industry".

Respondents indicated that if CBT is introduced in their area will be welcomed. They expect that it will motivation to coffee farmers to improve their activities, as its benefits will be extended to everybody in the coffee industry. Furthermore, the start-up of coffee-based tourism would help to take care of the coffee trees, since those who would be visited would be paid, and it would inspire others who have not been visited to improving the standards of their coffee threes.

On our side as a coffee washing stations, it would be interesting for us, because money farmers will get from tourism activities would motivate them to take care of their coffee. As a result, we will get higher yields and would enable us to produce more and better produce (GITWE CWS manager)

By the time we collected data for this study, CWS managers were experiencing the shortage coffee supply from farmers. Therefore, CBT would contribute to the increase of coffee yield as it will motivate farmers to look after their coffee trees as they will need to keep the farm always ready for tourists. "Here we have a shortage of produce mainly due to the way farmers take care of their coffee threes. Therefore, due to tourism, crops will grow for other years." (KARAMBI CWS manager).

The second expected benefit from CBT is to improve the coffee farmers' livelihood. This coffee-based trip would actually make a big contribution, especially to farmers. CBT would create many jobs for farmers and no farmers working in tourism related activities. Hence, unemployment in the district will decrease.

Furthermore, farmers will benefit because they will earn money from tourists visiting their farms. Furthermore, farmers will like their career as tourism activities will give it a value. "A farmer will have something else to make a living from and finding a valuable farming career. As tourists will be visiting him it will be another source of income, be able to build a good house as the business goes on". (KARAMBI CWS manager).

CBT will benefit both farmers and CWS as level of relationship between the 
company and farmers will improve. Motivated farmers because of CBT will produce a better quality of coffee cherries, and in big quantity. This will improve the relationship between farmers and he CWS as both will be making profits.

The third benefit from the introduction of CBT in Nyamasheke District is boosting the coffee industry. As it was stated above, some farmers are demotivated and wish to switch from coffee farming to other type of crops. This respondent can't wait to see CBT introduced in this district. "If tourism is introduced to farms in this district, coffee will be more valued. My suggestion is that this research should be done quickly and be implemented so that it can help farmers." (Coffee farmer 4).

The V/Mayor in Nyamasheke District indicated that the benefits will be huge because currently production is not enough. He expects that if tourism come in the area farmers will look after their farms better that before. "The benefits are huge, because we don't even get what we want because, coffee has to be taken care of so that it produces between three and five kilograms of coffee per tree. You see, production will go up, and the number of trees in Nyamasheke district will multiply".

Ammirato and Felicetti (2014) asserted that the concept of Agri-tourism has been introduced as a farm activity, that able to give sustainable development to rural communities (Ammirato \& Felicetti, 2014). According to Setiyorini (2019), it is obvious that coffee tourism has great potential to raise local communities' welfare. This is due to market opportunities and value-added benefits.

\subsection{Factors That May Promote or Hinder the C.B.T Development in the Study Area}

To identify factors that may promote CBT or hinder its success in the studied district, the study used SWOT analysis technique. The SWOT analysis consist of the analysis of the internal environment (which provides the analytical underpinning for the Strengths and Weaknesses) and the analysis of external environment (which provide the analytical underpinning for the Opportunities and Threats). Taghavifard et al. (2018), assert that Classic Strengths, Weaknesses, Opportunities and Threats (SWOT) analysis has been developed based on stable environment that means if the environment of an organization were steady, invariable, and predictable, the classic SWOT analysis could be performed for the organization, and it is useful and can solve some problems (Taghavifard et al., 2018). Strength Opportunity Weakness and Treat (SWOT) analysis was used before by (Taghavifard et al., 2018), in their study entitled "Development of Agri-tourism to Support Community-Based Tourism Toward Sustainable Agriculture". Therefore, this study used the SWOT analysis since it was proven to be effective tool for researches related to agri-tourism. In this research, the SWOT analysis was used to probe different factors that may hinder or promote the CBT in the studied area. 


\subsubsection{Factors Which May Promote CBT} Strengths

- The willingness of farmers, CWS managers and local leaders toward the introduction of CBT (see quotes above).

- Availability of enough coffee plantations in the area (NAEB, 2016).

- Availability of many Coffee Washing Stations (NAEB, 2016). Opportunities

- The availability of many attractions which can improve the district's attractiveness. For example, the historical sites like Nyabitekeri, King Rwabugiri site, a place where pregnant girls were being thrown in the Kivu Lake, good climate, Nyungwe National Park, etc. (The V/Mayor in Nyamasheke District).

- The plan of Nyamasheke district to boost the coffee cherries production from 13000 tonnes harvested in 2020 to 20000 tonnes of coffee cherries in 2021 (The V/Mayor in Nyamasheke District).

- The willingness of the Rwandan Government through RDB to develop small, medium and micro enterprise (SMME) in tourism sector (GoR, 2009).

\subsubsection{Factors That May Hinder the Success of CBT in Nyamasheke} District

Weakness

- Farmer's discouragement due to high production costs and unstable coffee price (see the above quotes).

- Lack of infrastructures like roads and accommodation necessary to facilitate tourism activities (Coffee farmer 4).

- Few CWS have the capacity to process coffee from the cherry coffee to the cup (Kivu Belt CWS manager).

Threats

$\checkmark$ Disease like Covid 19 which has affected tourism these past two years.

$\checkmark$ The lack of government's focus on the CBT development (see policy analysis).

$\checkmark$ Poor transport and communication infrastructure sometimes destroyed by rains and mud/landslides (DDP, 2013).

$\checkmark$ Disaster risks to livelihoods-loss of lives from mud/landslides and impassable roads affecting economic activities (DDP, 2013).

\subsection{Policy Gap in Relation to CBT}

While the Rwanda's Tourism Master Plan recognized coffee tourism as a potential "add-on product" to complement the core market of eco-tourism (GoR, 2009). The tourism policy of 2009 does not put coffee-base tourism among the list of priorities.

Instead, the policy focus on Community Based Tourism to include all form of tourism based on rural community. It says: "to the rural sector, Community-Based Tourism needs to be given a more demand-led approach to raise their economic 
viability. This Policy targets to support viable SMMEs, offering marketable tourism products and services that meet essential quality standards, as well as aiming to promote Community-Based Tourism." (GoR, 2009).

In this policy, CBT was not listed with other tourism products developed so that the country reduces its over dependence on Mountain Gorillas.

Instead, it is generalized among other Community based tourism sector, while coffee plant has its uniqueness and can have double benefits. Firstly, if it has the potential to contribute to the welfare of coffee farmers and foreign exchange to the government; secondly, satisfied farmers would look after their farms then they increase the quality and quantity of the Coffee Production.

The Rwandan tourism policy 2009 reveals that the government of Rwanda wants to establish a partnership between $\mathrm{RDB}$, private sector, local government and commercial banks to promote the Community-Based Tourism. The policy provides a detailed implementation plan indicating different programs, activities to be done, government organs in charge of accomplishing the stated activities as well as the budget for each activity. Some of them are the following:

○ Create tourism corridors (spokes) that provides linkages between Kigali (hub) and the Destination Management Areas (DMAs) and which will be enhanced by the development of community and cultural based tourism products; 284,000,000 Rwf;

O Identify and support commercially viable Community-based tourism initiatives that can make a contribution to poverty alleviation and conservation; money allocated to this project equal to 113,600,000 Rwf;

- Provide special training in communities in support of community-based tourism projects and SMMEs; the budget for this project equal to $170,400,000$ Rwf;

- Improving access to finance for SMMEs, in relation to viable business plans. The budget reserved for these initiatives is $56,800,000 \mathrm{Rwf}$;

- Highlight the necessity for community-based tourism products accessible to be remarkable. The budget for this initiative equal to 11,360,000 Rwf.

Even if the government has released this enormous money to boost the Community Based Tourism, no respondent of this study who indicated to have received any support to develop the Coffee Based Tourism. This is an indication that the CBT in the studied area was neglected by policy makers.

The report published by the National Agriculture Export Development Board (NAEB), entitled the National Coffee Census 2015, painted the picture of coffee production in Rwanda. It identified the number of coffee trees, the number of farmers, the number coffee Washing stations, and it ranked regions based on the number of coffee trees (NAEB, 2016).

However, the report is lacking the analysis of the productivity of coffee business and strategies to assist coffee farmers as well as CWSs in their daily activities. Furthermore, this report does not mention the CBT while according to the results of this study and experience from other countries CBT has the potential 
to improve the Coffee productivity in term of quality and quantity.

The latest DDP 2013-2018 of Nyamasheke district also did not include coffee based tourism in its strategic plan of the period between 2013-2018. The DDP put Coffee and Tea in the same category and does not treat them as a niche market on their own but as roadside tourism. It states that: "Coffee and tea will continue to be important cash crops in the district and road side tourism with tea and tourism is a possible tourist attraction."

The focus of the district is on increasing the quality and quantity of these crops for mainly export purpose. The DDP (2013-2018) states that:

"To further improve commercialization and post-harvest handling; the district will increase focus on export crops including coffee, tea and horticulture. Coffee is planned to expand by 1880 ha while tea is planned to expand by 1000 ha." (DDP, 2013).

Lyon (2013) reveals that the development of the coffee tour helped to strengthen the cooperative's organizational capacity in several specific ways, including the introduction of a diversified managerial structure, extensive training opportunities, and new professional positions.

While the benefits of CBT are evident the sucess for coffee tourism development in many African nations remains largely untapped because of a range of destination management and image issues (Anbalagan \& Lovelock, 2014). Therefore, governments should review their priority and develop this new and important tourism business as it has a potential for the rural development. Setiyorini (2019) state that in ensuring communities for tourism economic opportunities, government should intervene with a well-defined plan backed by a policy.

In coffee tourism development policy, government might emphasize several points, such as ensuring that local communities have the capability to employ economic opportunities; protecting the environment through zoning regulations initiation; and developing visitor management guidelines.

\section{Conclusion of the Study}

This study extends the findings of Anbalagan and Lovelock (2014) by analyzing the potential contributions of coffee based tourism to the coffee sector in Rwan$\mathrm{da}$, focusing on Nyamasheke district. It contributed to the ongoing debate around the benefits of coffee tourism on rural development. The study found that coffee-based tourism may provide two main benefits. Firstly, it may motivate farmers to look after their farms and the benefits gained from tourism activities maybe contribute to the improvement of farmers' livelihood. Secondly, the CBT may contribute to development of the coffee industry as the quality and quantity would improve as a result of the introduction of the CBT. Furthermore, the country's economy would be improving due to the income coming from coffee exports and inbound tourists.

Among factors that may contribute to the success of the CBT in the study are; the willingness of players in the industry to try it, the availability of coffee farms, 
as well as other attractions in the region. Factors that may hinder the success of this new venture are farmers' demotivation due to the high production cost of running this business, the fluctuation of coffee price, poor infrastructures, pandemic and diseases like COVID-19, and the lack of government focus on this new tourism product.

The success of this new venture will depend heavily on the political will at the central government as well as the local government. The Rwandan government through deferent institutions needs to develop a policy on CBT as well as provide supports needed to develop this new business venture. These would include coffee farmers training in business management, marketing the CBT and providing funds to support CBT business.

\section{Conflicts of Interest}

The authors declare no conflicts of interest regarding the publication of this paper.

\section{References}

Agricultural Council of Tanzania (ACT) (2018). Agritourism Regions for Enhancing Linkages between Tourism and Sustainable Agriculture in the United Republic of Tanzania. Agricultural Council of Tanzania.

Ammirato, S., \& Felicetti, A. (2014). The Agritourism as a Means of Sustainable Development for Rural Communities: A Research from the Field. The International Journal of Interdisciplinary Environmental Studies, 8, 17-29. https://doi.org/10.18848/2329-1621/CGP/v08i01/53305

Anbalagan, K., \& Lovelock, B. (2014). The Potential for Coffee Tourism Development in Rwanda-Neither Black nor White. Tourism and Hospitality Research, 14, 81-96. https://doi.org/10.1177/1467358414529579

Ashley, C. (2007). Pro-Poor Analysis of the Rwandan Tourism Value Chain. An Emerging Picture and Some Strategic Approaches for Enhancing Poverty Impacts (p. 44). Overseas Development Institute.

CBI (2018, July 27). Value Chain Analysis for Coffee Sector in Rwanda. Central Bureau of Investigation.

Clay, D. C., Bro, A. S., Church, R. A., Bizoza, A., \& Ortega, D. L. (2016). Determinants of Farmer Investment in Coffee Production: Finding a Path to Sustainable Growth in Rwanda's Coffee Sector. No. 1098-2016-88853, Michigan State University.

District Development Plan (DDP) (2013). Nyamasheke District Western Province: District Development Plan (2013-2018).

Govea, F. E. D., \& Lin, C. N. (2015). Using AHP to Analyze the Motivation of Taiwan Eco-Agritourism by Foreign Visitors. Rural Development Perspectives, 20, 37-52.

Government of Rwanda (GoR) (2009). Sustainable Tourism Master Plan for Rwanda. Government of Rwanda.

International Coffee Organization (2020, June). Impact of Covid-19 on the Global Coffee Sector: Survey of ICO Exporting Members. Coffee Break Series No. 3, International Coffee Organization.

https://www.ico.org/documents/cy2019-20/coffee-break-series-3e.pdf 
Khanal, S., \& Shrestha, M. (2019). Agro-Tourism: Prospects, Importance, Destinations and Challenges in Nepal. Archives of Agriculture and Environmental Science, 4, 464-471. https://doi.org/10.26832/24566632.2019.0404013

Lyon, S. (2013). Coffee Tourism and Community Development in Guatemala. Human Organization, 72, 188-198. https://doi.org/10.17730/humo.72.3.0011g4xj1m83x68j

Mahaliyanaarachchi, R. P. (2014). Agro Tourism. Department of Agribusiness Management, Faculty of Agriculture Sciences, Sabaragamuwa University of Sri Lanka.

MINAGRI (Ministry of Agriculture and Animal Resources) (2018). Rwanda Strategic Plan for Agriculture Transformation 2018-2024. Ministry of Agriculture and Animal Resources

NAEB (National Agricultural Export Development Board) (2016). National Coffee Census 2015. National Agricultural Export Development Board.

Nickerson, N. P., Black, R. J., \& McCool, S. F. (2001). Agri-Tourism: Motivations behind Farm/Ranch Business Diversification. Journal of Travel Research, 40, 19-26.

https://doi.org/10.1177/004728750104000104

NISR (National Institute of Statistics of Rwanda) (2012). Fourth Population and Housing Census-2012.

Setiyorini, H. D. (2019). Coffee Tourism Development Potential: Benefit and Consequences. 3rd International Seminar on Tourism (ISOT 2018) (pp. 154-157). Atlantis Press. https://doi.org/10.2991/isot-18.2019.33

Sharpley, R., \& Vass, A. (2006). Tourism, Farming and Diversification: An Attitudinal Study. Tourism Management, 27, 1040-1052. https://doi.org/10.1016/j.tourman.2005.10.025

Taghavifard, M. T., Amoozad Mahdiraji, H., Alibakhshi, A. M., Zavadskas, E. K., \& Bausys, R. (2018). An Extension of Fuzzy SWOT Analysis: An Application to Information Technology. Information, 9, Article No. 46. https://doi.org/10.3390/info9030046

Thapa, D. (2013). Development of Agri-Tourism in Nepal, an Alternative to Emigration for Nepalese Youths: Case: BishramBatika Restaurant. Thesis submitted to Centria University of Applied Science, Degree Programme in Tourism.

Thorp, Z. W. (2015). Agri-Tourism in Kansas: Effects of Distance and Economic Outcomes. Doctoral Dissertation, University of Kansas.

UN-Rwanda (United Nations in Rwanda) (2014). Support to the Development and Implementation of Value Chains Program in Rwanda. United Nations in Rwanda.

Veeck, G., Che, D., \& Veeck, A. (2006). America's Changing Farmscape: A Study of Agricultural Tourism in Michigan. The Professional Geographer, 58, 235-248. https://doi.org/10.1111/j.1467-9272.2006.00565.x

Williams, C. (2011). Research Methods. Journal of Business \& Economics Research (JBER), 5, 65-71. https://doi.org/10.19030/jber.v5i3.2532

Woyesa, T., \& Kumar, S. (2021). Potential of Coffee Tourism for Rural Development in Ethiopia: A Sustainable Livelihood Approach. Environment, Development and Sustainability, 23, 815-832. https://doi.org/10.1007/s10668-020-00610-7 